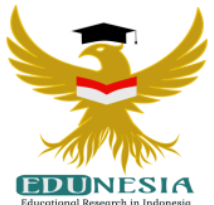

\title{
Development of SAVI-Based LKPD to Improve Critical Thinking of V Grade Students of SDIT Wahdatul Ummah
}

\author{
Reni Febriyanti ${ }^{1}$; Alben Ambarita²; Rochmiyati $^{3}$ \\ 1,2,3 Department of Primary Education, Universitas Lampung, Indonesia \\ ${ }^{1}$ Corresponding Email: renifebriyanti42@guru.sd.learning.id, Phone Number: 0896 xxxx xxxx
}

\author{
Article History: \\ Received: July 15, 2021 \\ Revised: August 12, 2021 \\ Accepted: August 24, 2021 \\ Online First: August 28, 2021
}

\section{Keywords:}

Critical Thinking,

SAVI,

Worksheets.

\section{Kata Kunci:}

Berpikir Kritis,

Lembar Kerja,

SAVI.

\section{How to cite:}

Febriyanti, R., Ambarita, A., \& Rochimayati, R. (2021) Development of SAVI-Based LKPD to Improve Critical Thinking of V Grade Students of SDIT Wahdatul Ummah. Edunesia: Jurnal Ilmiah Pendidikan, 2 (3): 650-662.

This is an open access article under the $C C$-BY-NC-ND license

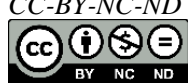

\begin{abstract}
Purpose of this research and development is to describe the validity and effectiveness of developing student worksheets based on the SAVI learning model in improving students' critical thinking skills. This type of research is research and development that refers to the theory of Borg and Gall. The population of this study was the fifth grade elementary school students in East Metro District and the sample was determined by purposive sampling as many as 40 students divided into experimental and control classes. Data was collected through observation sheets, questionnaires, and test questions. The data analysis technique used is the n-Gain test to determine its effectiveness. The results of the validation of the SAVI-based student worksheets were carried out by material, media and language experts. The results showed that the SAVI-based student worksheet development product was valid and effective for use in the fifth grade student learning process. This was evidenced by the improvement in students' critical thinking after using the SAVI-based student worksheet.
\end{abstract}

\begin{abstract}
Abstrak: Tujuan dari penelitian dan pengembangan ini adalah untuk mendeskripsikan kevalidan dan efektivitas pengembangan lembar kerja peserta didik berbasis model pembelajaran SAVI dalam meningkatkan keterampilan berpikir kritis peserta didik. Jenis penelitian ini adalah penelitian dan pengembangan yang mengacu pada teori Borg and Gall. Populasi penelitian ini adalah siswa kelas V Sekolah Dasar di Kecamatan Metro Timur dan sampel ditentukan secara purposive sampling sebanyak 40 peserta didik terbagi pada kelas eksperimen dan kontrol. Pengumpulan data dilakukan melalui lembar observasi, angket, dan soal tes. Teknik analisis data yang digunakan adalah uji n-Gain untuk mengetahui efektivitasnya. Hasil validasi lembar kerja siswa berbasis SAVI dilakukan oleh ahli materi, media, dan bahasa. Hasil penelitian menunjukkan bahwa produk pengembangan lembar kerja siswa berbasis SAVI yang dihasilkan valid dan efektif untuk digunakan dalam proses pembelajaran siswa kelas V. Hal ini dibuktikan dengan peningkatan berpikir kritis peserta didik setelah menggunakan lembar kerja peserta didik berbasis SAVI.
\end{abstract}




\section{A. Introduction}

Facing the era of the industrial revolution 4.0, the world of education is required to be able to adapt to the times without losing the values of the nation's personality and culture. Education has an important role in the formation and development of the quality of human resources in the face of the times. Education is one of the benchmarks for the level of progress of a nation. In addition, education is also an important element in improving the dignity and quality of human life. Education is a process of inculcating culture, norms and moral values in society to an individual or group that includes knowledge, behavior, and socio-culture. This cultivation process runs gradually and continuously as long as humans live. Education aims so that later people who receive education can adapt to the community environment and benefit the people around them. Education in Indonesia needs to prepare for this 4.0 revolution by making some changes in implementing the learning model in schools. 21st century learning must be able to boost people's welfare and be able to create the next generation of the nation that is intelligent, tough, characterized, and able to compete and answer the challenges of the era of globalization. First, the fundamental thing is to change the nature and mindset of students, secondly to be able to hone and develop children's talents and thirdly educational institutions must be able to change learning models according to the needs of the times. Education in Indonesia is no longer just talking about classic problems, namely equity and fulfillment of access, facilities and infrastructure, but also talking about the quality of graduates who are able to compete with the demands of development.

Learning in the 21st century requires students to be actively involved in the learning process so that students get experience that can train and develop their thinking skills. Education must create human resources that are critical and adaptive to changes and progress that occur and are able to overcome problems that occur along with developments. Students are trained to face various problems by involving insight, creativity, mindset in solving problems, as well as communication and cooperation between students. The various problems that arise require students to further maximize their competence and thinking power to face the challenges of the 21st century and compete in the global era. The abilities that must be possessed by students in the 21st century are collaboration (the ability to work well together), communication (skills), creativity (creativity), and critical thinking (critical thinking). The results of research conducted by Iskandar (2016), stated that: "This research was motivated by the lack of critical thinking skills of fourth grade students. On this base, it is necessary to make good improvements by applying the SAVI (Somatic, Auditory, Visualization, Intellectual) model, with the aim of knowing the improvement of students' critical thinking skills. From these results it can be concluded that applying the SAVI learning model with social problems in the local environment can improve students' critical thinking skills."

Critical thinking is related to the assumption that thinking is a potential that exists in humans that needs to be developed for optimal abilities. The results of the research by Adistyaningrum (2020), stated that: "The result of the research reveals that the SAVI approach with macroflash is considered effective in increasing the critical thinking ability of the 2nd grade students of SMA Negeri 1 Depok Sleman in excretion system subject."

Fitriyani, et al (2020) found that students' critical thinking skills were still in the poor category. This is partly due to the lack of classroom learning that trains students to think critically. Ability Critical thinking (critical thinking) is needed in social life, so this needs to be embedded in learning. What happens at school, the teacher only emphasizes the material, 
so that the ability students think in Indonesia is still relatively low. This can be seen from the results of the Program for International Student Assessment 2018(PISA) study which was released on Tuesday, December 3, 2019, data showed that Indonesia's reading index was 371, mathematics was 379, and science performance was 396.

Based on the results of the study, Indonesia's performance appears to be declining. in 2018, when compared with 2015 PISA results. This 2018 study assessed 600,000 15-yearolds from 79 countries conducted every three years. The study compared the math, reading, and science performance of each child. As for the reading ability category, Indonesia is ranked 6th from below, aka 74th. Indonesia's average score is 371, under Panama which has an average score of 377. While the first place is occupied by China with an average score of 555. Singapore is in second place with an average score of 549 and Macau, China is in third place with an average score of 525 . While Finland, which is often used as a model for the education system, is in 7th place with an average score of 520.

In the mathematics category, Indonesia is in ranked 7th from the bottom with an average score of 379. Indonesia is above Saudi Arabia which has an average score of 373. Then for first place, China is still occupied with an average score of 591. Then for the category of science performance, Indonesia is in ranked 9th from the bottom, with an average score of 396. It is above Saudi Arabia which has an average score of 386. China is in first place with an average score of 590. Indonesia's participation in the International Trends in International Mathematics and Science Study (TIMSS) and Program for International Student Assessment (PISA) studies since 1999 also shows that the achievements of Indonesian children are not encouraging in several reports issued by TIMSS and PISA. This is because, among other things, the number of test materials asked in TIMSS and PISA are not included in the Indonesian curriculum and the low quality of reading proficiency Pratiwi (2019) states that Indonesian mathematics learning is still not appropriate. The PISA standard uses the HOTS education system while Indonesia still uses LOTS so that it is not connected, which also triggers Indonesia's low PISA results.

PISA emphasizes the 21st century skills that enable inclusion in the education system. In the OECD issue of "The Future of Education and Skills: An OECD 2030 Framework" that as many as 21 countries do not have a curriculum that focuses on future planning needed. In fact, one of the things needed by the 21st century is critical thinking (OECD, 2018). Critical thinking skills are needed in finding alternative problem solving solutions, and critical thinking is a basic ability that is a determining factor in problem solving (Thompson, 2011). On the other hand, the process of solving a problem can also train students' critical thinking skills. This statement also encourages researchers to know critical thinking skills. So that the results of the TIMSS and PISA assessments obtained can be an illustration of the low critical thinking ability in the learning process. Learning is still at the achievement of learning objectives at the level of understanding and applying. So that the learning process is not able to develop the skills possessed by students. Learning is said to be successful and of high quality if most of the students are actively involved, physically, mentally and socially in the learning process. Learning takes place as a two-way process between teachers and students in teaching and learning activities. Based on the above, the teacher's efforts in developing student learning activities are very important, because student learning activities are the determinants of the success of the learning carried out.

The results of preliminary research conducted on 04-05 August 2020 at SD/MI Gugus Kartini, East Metro District which consisted of SDN 4 Metro Timur, SDN 5 Metro Timur, and SDIT Wahdatul Ummah Metro Timur showed that 6 out of 7 educators did not 
apply learning that can improve ability critical thinking. Then it was found that 5 out of 7 educators did not have other learning resources such as LKPD in the learning process, and 7 educators did not know about SAVI-based LKPD. In addition, the results of the questionnaire analysis of student needs regarding the learning process obtained data that as many as $52 \%$ did not have other learning resources other than theme books, then as many as $57 \%$ of students stated that they were not required to think critically. Then $63 \%$ of educators do not provide LKPD during teaching and learning activities and $75 \%$ of students do not have other learning resources such as LKPD in the learning process. Therefore, in the implementation of teaching and learning activities, it is increasingly demanding to develop LKPD based on the SAVI approach.

Based on the explanation above and the results of the needs analysis questionnaire, it is necessary to have a learning process that can involve students more critically through somatic, audio, visual, and intellectual learning resources, which aims to create meaningful learning for students. For this reason, it is necessary to develop LKPD based on the SAVI learning model for fifth grade at SDIT Wahdatul Ummah Metro Timur.

\section{B. Method}

Research and development (RED) is the method used in this research. The development procedure is based on the Borg \& Gall model (1989) through several stages including: 1) initial information collection, 2) planning, 3) initial product form development, 4) initial trial, 5) initial product revision, 6) field test for the main product, and 7) revision of the main product. The implementation of preliminary studies and trials of LKPD tools was carried out at SDIT Wahdatul Ummah, while the process of developing learning tools was carried out on the campus of the University of Lampung. The research subjects were LKPD based on the SAVI learning model, while the product trial subjects were fifth grade elementary school students. The population in this study were fifth grade elementary school students in North Raman District.

In this study, the sampling technique used is the purpose sampling technique. The research sample was the fifth grade students of SDIT Wahdatul Ummah totaling 40 students consisting of the experimental and control classes. Data collection techniques in this development research are using non-test techniques and test techniques. The effectiveness of the use of LKPD is seen from the learning outcomes of students as well as to measure students' critical thinking skills. The data is in the form of quantitative data obtained through pre-test and post-test.

\section{Result and Discussion \\ Result}

\section{Results of developing student worksheet based on the SAVI learning model for class V students at SDIT Wahdatul Ummah}

Results of developing student worksheets based on the SAVI learning model for Class V. The following results were obtained.

\section{1) Research and Information Collection}

Information is collected through observation and interviews Based on the results of the questionnaire analysis of the needs of students and teachers as well as the results of 
observations obtained data 1) Educators do not apply learning where students are able to solve problems with abilities critical thinking. 2) Students are not required to think critically in the learning process. 3) Educators have difficulty in developing LKPD. 4) There is no SAVI-based LKPD.

\section{2) Planning}

Planning is done by analyzing the results of information collection. The product to be developed is a learning device consisting of a syllabus, lesson plans, worksheets and assessment instruments. Furthermore, the authors systematically compile the basic competencies, indicators, and learning objectives developed in this study. The chosen theme and sub-theme is the theme 'Our Friends Environment' in class V.

\section{3) Product development}

Activity is carried out part by part in accordance with the LKPD framework that has been prepared. The preparation of draft thisconsists of 1) cover, preface, table of contents, mapping of core \& basic competencies, and indicators, learning objectives, instructions for using student worksheets based on the SAVI learning model, concept maps, and compiling the contents of student worksheets in accordance with SAVI learning steps.

\section{4) Initial Field Testing}

This product trial stage is the stage of testing the designed student worksheets. The evaluation was designed through expert validation and student responses through small class trials. At this stage, testing is carried out on the resulting product in the form of validation by experts, practitioners, and students before being used in the implementation stage. In the validation test, the data collection technique used is also in the form of a questionnaire to see the characteristics which include construction, content suitability, and readability of the developed product. From the results of the validity sheet filled in by education experts, it can be seen in the following assessment:

a) Material expert test validation results

Table 1. Material expert validation assessment score

\begin{tabular}{llcc}
\hline No & Aspect of assessment & Total score & $\begin{array}{c}\text { Score } \\
\text { maximum }\end{array}$ \\
\hline 1 & Quality content & 17 & 24 \\
\hline 2 & Presentation materials & 17 & 20 \\
\hline Total score & 34 & 48 \\
\hline Value & \multicolumn{3}{c}{70,83} \\
\hline Category & \multicolumn{2}{c}{ Pretty good } \\
\hline Source: Expert assesment material & \multicolumn{3}{c}{}
\end{tabular}

Based on the results of the assessment above, a score of 70.83 was obtained in the "Good enough" category. Some suggestions are given, among others, the formulation of indicators developed must refer to critical thinking indicators. The material presented must cover SAVI aspects, namely somatic, audio, visual, and intellectual. 


\section{b) Linguist Test Validation Results}

Validation assessment carried out by linguists includes the following aspects.

Table 2. Linguistics expert validation assessment score

\begin{tabular}{clcc}
\hline No & \multicolumn{1}{c}{ Aspect of assessment } & Total score & $\begin{array}{c}\text { Score } \\
\text { maximum }\end{array}$ \\
\hline 1 & $\begin{array}{l}\text { Language suitability with the } \\
\text { level of development of } \\
\text { students }\end{array}$ & 11 & 12 \\
\hline 2 & $\begin{array}{l}\text { Language use meets the } \\
\text { requirements for coherence } \\
\text { and coherence in the flow of } \\
\text { thinking }\end{array}$ & 7 & 8 \\
\hline $3 \quad \begin{array}{l}\text { Use of communicative } \\
\text { language }\end{array}$ & 8 & 8 \\
\hline Total score & 26 & \multicolumn{2}{c}{92,82} \\
\hline Value & \multicolumn{2}{c}{ Very good } \\
\hline Category
\end{tabular}

Source: Linguist assessment

Based on the results of the assessment above, a score of 92.82 was obtained. With the category "Very Good". Some of the suggestions given by linguists have been used to revise the product. The results of product revisions include giving an introduction in starting an activity, paying attention to the use of EYD in a sentence, and using appropriate illustrations in the reading text according to the characteristics of students.

\section{c) Media Expert Test Validation Results}

Assessment carried out by media experts, can be seen in the following aspects.

Table 3. Assessment score of media expert validation

\begin{tabular}{clcc}
\hline No & \multicolumn{1}{c}{ Aspect of assessment } & Total score & $\begin{array}{c}\text { Score } \\
\text { maximum }\end{array}$ \\
\hline 1 & Attractiveness of LKPD & 10 & 12 \\
\hline 2 & Presentation of LKPD & 8 & 8 \\
\hline $3 \quad$ Organization in LKPD & 10 & 12 \\
\hline $4 \quad \begin{array}{l}\text { Cultivating critical thinking } \\
\text { skills }\end{array}$ & 2 & 4 \\
\hline Total score & 30 & 36 \\
\hline Valeu & \multicolumn{3}{c}{80,33} \\
\hline Category & \multicolumn{3}{c}{ Good } \\
\hline
\end{tabular}

Source: Media expert assessment

Based on the results of the above assessment, the score obtained is 80.33 with the "Good" category. Researchers revise the product based on suggestions given by media experts, including: adjusting the size of images and writing to make it look proportional to 
the paper used, fixing the location of images and text boxes to make them look symmetrical, and pay attention to the color of the image on the instruction sheet used so that students can easily distinguish each instruction given.

\section{d) The results of the validation of the practitioner test}

The validation assessment carried out by the fifth grade educator of SDIT Wahdatul Ummah is as follows.

Table 4. Assessment score validation of class V elementary school teachers

\begin{tabular}{|c|c|c|c|}
\hline No & Aspect of assessment & Total score & $\begin{array}{c}\text { Score } \\
\text { Maximum }\end{array}$ \\
\hline 1 & $\begin{array}{l}\text { Language suitability with } \\
\text { the level of development of } \\
\text { students }\end{array}$ & 12 & 12 \\
\hline 2 & $\begin{array}{l}\text { Language use meets the } \\
\text { requirements for coherence } \\
\text { and integration of the flow } \\
\text { of thinking }\end{array}$ & 7 & 8 \\
\hline 3 & $\begin{array}{l}\text { Use of communicative } \\
\text { language }\end{array}$ & 8 & 8 \\
\hline 4 & Attractiveness of LKPD & 11 & 12 \\
\hline 5 & Presentation of LKPD & 7 & 8 \\
\hline 6 & Organization in LKPD & 10 & 12 \\
\hline 7 & $\begin{array}{l}\text { Cultivating critical thinking } \\
\text { skills }\end{array}$ & 3 & 4 \\
\hline \multicolumn{2}{|c|}{ Total score } & 58 & 64 \\
\hline \multicolumn{2}{|c|}{ Value } & \multicolumn{2}{|c|}{90,62} \\
\hline \multicolumn{2}{|c|}{ Category } & \multicolumn{2}{|c|}{ Very good } \\
\hline
\end{tabular}

Source: Assessment of grade V elementary educators

Based on the results of the above assessment, obtained a score of 90.62 with "Very Good" category. Thus, this LKPD deserves to be continued because it has fulfilled the aspects of making LKPD.

\section{e) Small group Trial}

Results of small group trials to see the improvement of critical thinking skills and student learning outcomes. Based on the results of observations, it can be seen that of the 20 students in the small group there are 3 students (15\%) in the very good category, 11 students $(55 \%)$ in the good category, 6 students $(30 \%)$ in the fairly good category, and there are no students in the low category. Students are said to think critically if there are aspects that show indicators of critical thinking abilities. During the learning process, students are able to provide simple explanations, are able to build basic skills, and are able to conclude. Based on the description above, it can be concluded that the SAVI-based LKPD can improve students' critical thinking skills in small group trials. 
In addition, based on the learning outcomes of small group students, it is known that there is an increase in the results of the pretest with theresults posttest before and after using the SAVI-based LKPD. The average $N$-Gain in the small group trial was 0.40 (medium category). The average score pretest was 67.43 and increased to 80.43 at theaverage posttest. Thus, it is concluded that there is an increase in student learning outcomes after participating in learning using SAVI-based LKPD in small group trials.

\section{5) Revision of Initial Product}

The results of the revision of the LKPD are based on suggestions given by media experts, among others 1) adjust the size of the images and writings so that they look proportional to the paper used. 2) Fix the layout of images and text boxes to make them look symmetrical. 3) Pay attention to the color of the image on the instruction sheet used so that students can easily distinguish each instruction given. Subsequent revisions were made based on suggestions for improvement provided by linguists. The results of the revision of the LKPD are based on the suggestions given by linguists, namely: 1) give an introduction in starting an activity. 2) Notice the use of EYD in a sentence. 3) Use the right illustrations in the reading text according to the characteristics of the students.

After the revision stage was carried out and all validators of material experts, media experts, linguists, and SDIT Wahdatul Ummah educators stated that the SAVI-based LKPD development product was feasible to use. The next step is product testing in the field.

\section{6) Main field trial}

\section{a) Observation results of critical thinking ability}

Assessment of critical thinking skills is obtained based on the results of student observations during learning activities using SAVI-based LKPD in class VB SDIT Wahdatul Ummah Metro Timur. The recapitulation of students' critical thinking skills in large groups is as follows.

Table 5. Recapitulation of thinking ability observation results critical students large group

\begin{tabular}{clcc}
\hline Score & Category & Frequency & Percentage (\%) \\
\hline $81-100$ & Very Good & 4 & 20,00 \\
\hline $61-80$ & Good & 12 & 60,00 \\
\hline $41-60$ & Enough & 4 & 20,00 \\
\hline $21-40$ & Low & 0 & 0 \\
\hline $0-20$ & Very Low & 0 & 0 \\
\hline & Total & 20 & 100
\end{tabular}

Source: Calculation results

Based on the table above, it can be described that the critical thinking skills of 20 students in a large group are 4 students $(20.00 \%)$ in the very good category, 12 students $(60.00 \%)$ with good category, 4 students $(20.00 \%)$ with good enough category, and no students with low category. These data indicate that students' critical thinking skills are 
good during the learning process using SAVI-based worksheets. The following is a recapitulation table of the average indicators of students' critical thinking skills.

Table 6. Summary of average indicators ability of critical thinking of students

\begin{tabular}{cccc}
\hline \multirow{2}{*}{ Learning } & \multicolumn{3}{c}{ Critical Thinking Skills Indicator } \\
\cline { 2 - 4 } & $\mathbf{1}$ & $\mathbf{2}$ & $\mathbf{3}$ \\
\hline 1 & 75,55 & 69,55 & 70,80 \\
\hline 2 & 77,00 & 72,85 & 71,45 \\
\hline 3 & 80,40 & 73,50 & 75,35 \\
\hline 4 & 81,55 & 77,20 & 80,85 \\
\hline 5 & 82,00 & 80,00 & 83,57 \\
\hline 6 & 83,00 & 82,71 & 85,43 \\
\hline Total & 479,50 & 455,81 & 467,45 \\
\hline Average & 79,92 & 75,97 & 77,91 \\
\hline Category & Good & Good & Good \\
\hline
\end{tabular}

Source: Calculation results

\section{b) Learning outcomes student learning}

Outcomes are obtained from thescores pretest conducted before the learning activities and from thescores posttest conducted at the end of the lesson. This is intended to see the effectiveness of SAVI-based LKPD, whether there is an increase in student learning outcomes before and after learning is carried out using SAVI-based LKPD. The following is the data of large group learning outcomes.

Table 7. Summary of results large group learning

\begin{tabular}{ccccc}
\hline \multirow{2}{*}{ Clasroom } & \multicolumn{2}{c}{ Avarage score } & \multirow{2}{*}{ N-Gain } & \multirow{2}{*}{ Category } \\
\cline { 2 - 3 } & Pretest & Posttest & & \\
\hline VB & 57,76 & 74,88 & 0,53 & Medium \\
\hline
\end{tabular}

Source: Calculations pretest and posttet large group

Data recapitulationBased on the study of students large group, known that there is an increase in yield. The averagelearning outcomes pretest of students in class VB was 57.76 andresults posttest increased to 74.88 . The average N-Gain is 0.53 (medium category). The table above shows an increase in learning outcomes which also shows the results of students' critical thinking skills after learning using SAVI-based worksheets theme 8 subtheme 3.

\section{Effectiveness of Student Worksheets Based on SAVI Learning Model}

Results N-Gain pretest-posttest after being calculated and presented in the following table 
Table 8. Results of N-Gain

\begin{tabular}{cccc}
\hline Aspect & Pretest & Posttest & N-Gain \\
\hline Average & 57,76 & 74,88 & 0,53 \\
\hline
\end{tabular}

Source: Calculation results N-Gain

Based on the table above, it is known that the average $N$-Gain results show the results of 0.53 which means that the N-Gain normalizedis in the "Medium" classification, then the level of effectiveness is effective. Thus, it can be seen that the SAVI-based LKPD effective in growing students' critical thinking skills. Furthermore, to be able to see the improvement of students' critical thinking skills, researchers will explain more clearly the analysis of student learning outcomes on each critical thinking dimension used in research. The results of the analysis can be seen in the following table.

Table 9. Results of analysis of critical thinking critical thinking

\begin{tabular}{lccc}
\hline \multirow{2}{*}{$\begin{array}{c}\text { Critical Thinking } \\
\text { Indicator }\end{array}$} & \multirow{2}{*}{$\begin{array}{c}\text { Number of } \\
\text { Quetions }\end{array}$} & $\begin{array}{c}\text { Average } \\
\text { (Category) }\end{array}$ & $\begin{array}{c}\text { Posttest } \\
\text { (Category) }\end{array}$ \\
\cline { 3 - 4 } $\begin{array}{l}\text { Provides simple } \\
\text { explanations }\end{array}$ & $1,2,6,7,11,12,18,19$ & 55,62 & 80,52 \\
\hline Building basic skills & $3,4,8,9,13,14,16,17$, & 39,55 & 70,05 \\
& $20,21,23,24$ & Low & Good \\
\hline Summing & $5,10,15,22,25$ & 40,82 & 74,52 \\
& & Low & Good \\
\hline
\end{tabular}

Source: Results of critical thinking indicator analysis

Based on the table above, it can be seen that the ability of students in each critical thinking indicator has increased. The increase is the average value for the ability to provide simple explanation indicators from 55.62 (enough category) to 80.52 (good category); the average value for the indicator of building basic skills from 39.55 (low category) increased to 70.05 (good category); the average value for the indicator concluded from 40.82 (low category) increased to 74.52 (good category). Based on these data, it is known that there is an increase in the critical thinking ability of class $\mathrm{V}$ students.

\section{Discussion}

\section{Feasibility of SAVI}

The feasibility of SAVI-based LKPD in thematic learning in class V theme 8 The Environment of Our Friends with the subtheme 3 Environmental Preservation Efforts, can be described as follows. The development of SAVI-based LKPD adapts the six steps of R\&D by Borg and Gall, the first stage is collecting initial information, after researchers know the problems that occur, researchers plan to develop LKPD that will be used by students so that they can improve critical thinking skills seen from learning outcomes learners. Next, the researcher compiled the initial product development of the LKPD, in this step the researcher outlined the pattern of development that would be carried out in the SAVI-based LKPD. The next stage is the initial trial. At this stage the researchers conducted validation tests and 
small group trials. The validation test was carried out by three validators, namely material experts, language experts, media experts, and fifth grade educators with the aim of validating the developed product whether it was in accordance with the development requirements so that it was feasible to be tested.

After conducting a validation test by experts, the researcher revised the product on the suggestions and comments from the validators. Next is the small group trial phase involving 10 students. Based on the results of small group trials, there is an increase in student learning outcomes before and after using the SAVI-based LKPD, the average score on the pretest is 56.40 , increasing to 72.80 on the average posttest score. Then the researchers made revisions to improve the product.

Next is the field trial phase (large group), student learning activities contained in the LKPD using the syntax design, design, and material in the student worksheet (LKPD) and learning implementation materials using SAVI theory. According to Rahayu, et al (2019) there are four stages that can be done in LKPD, namely preparation, delivery, training, and delivery of results. The learning steps begin with the preparation of students, namely by doing a stimulus through observing, reading, and asking questions. Then, the delivery of material with assignment and experimental activities. This process trains students to be able to conceptualize their own understanding. After getting a learning experience, students are able to display results through demonstration activities based on the information and facts obtained.

The sixth meeting in the field trial, the researchers tested the effectiveness of LKPD in improving critical thinking skills. Data acquisition of student learning outcomes showed an increase in the results of the pretest and posttest. So it can be concluded that the product developed is effective in thematic learning and improves students' critical thinking skills.

The SAVI-based LKPD product that has been developed has fulfilled the concept of learning and learning. The development of the SAVI-based LKPD is designed so that students can observe, experience for themselves, and obtain information available in the LKPD in the form of text, images, illustrations, or activity steps, thus encouraging students to construct knowledge with their own experience. This is in accordance with the opinion of Yildirim (2011) which states that "worksheets are known to help students gain scientific process skills such as setting up experimental mechanisms, recording data, interpreting the data, and so on so that they can conceptualize the concepts in their minds" . LKPD is part of a teaching resource that can encourage students to generate their own thoughts, ask questions, make connections, and evaluate results, so that students' independence can increase. In addition, Susantini (2016) states that the use of LKPD in the learning process helps students to understand the material by themselves.

LKPD also provides a great opportunity for students to show their abilities and develop thinking processes through discovery, observation and logical thinking. In line with the opinion of Noone and Hogan (2016) states that "Critical thinking is considered a metacognitive process involving skills such as analysis, evaluation and inference that, when used appropriately, increase the chances of producing a logical conclusion to an argument or solution to a problem." Critical thinking is a metacognitive process that involves the skills of analysis, evaluation, and inference, can improve logical conclusions in problem solving.

\section{Effectiveness of SAVI-Based LKPD Effectiveness}

The effectiveness test was conducted to determine the effectiveness of SAVI-based LKPD in the learning process that has been carried out and student learning outcomes that 
refer to critical thinking skills. The effectiveness test was conducted on 20 students of class VB SDIT Wahdatul Ummah Metro Timur. The LKPD that was tested included the theme material 8 The Environment of Our Friends, sub-theme 3 Environmental Preservation Efforts that had been previously designed. The results of the observation of critical thinking skills in the large group there are 4 students $(20.00 \%)$ in the very good category, 12 students $(60.00 \%)$ in the good category, 4 students $(20.00 \%)$ in the fairly good category, and there are no students in the low category.

Based on the effectiveness test using N-Gain, the students' critical thinking learning outcomes after using the SAVI-based LKPD were higher than before using the LKPD. The results of the recapitulation of the average N-Gain in the field trial obtained an average NGain of 0.53 which means that the normalized Gain is in the "Medium" classification, then the level of effectiveness is effective. SAVI-based LKPD can be said to be effective for improving students' critical thinking skills if student learning outcomes after using SAVIbased LKPD are higher than before using SAVI-based LKPD. The results of the analysis show the average rank and total score difference between the pretest and posttest scores.

\section{Conclusion}

Based on the analysis of research and development data with the title "Development of Somatic, Audio, Visual, and Intellectual LKPD to Improve Critical Thinking Skills for Class V Elementary School Students" it can be concluded that the SAVI-based LKPD product developed is feasible to use, this is evidenced by the validation results. the linguist got a score of 92.82 and the "Very Good" category, the validation of the media expert got a score of 80.33 and the "Good" category, and the validation of the VB class teacher with a value of 90.62 and the category "Very Good".

Based on the suggestions and validation results, the SAVI-based LKPD is declared valid and feasible to be used as teaching material in class V. SAVI-based LKPD is effectively used in the learning process for VB class students of SDIT Wahdatul Ummah Metro Timur to improve critical thinking skills. This is evidenced by the learning outcomes of students on the pretest and posttest scores obtaining a Gain of 0.53 in the "Medium" category.

\section{Reference}

Adistyaningrum. (2020). The Effectiveness of SAVI Approach with Macromedia Flash Toward Students' Critical Thinking Ability. Advances in Social Science, Education and Humanities Research. Vol. 397. 1031 - 1037.

Brog, Walter R., dan Gall, Meredith Damien. (1989). Education Research. New York.

Fitriyani, Y., Fauzi, I., \& Sari, M. Z. (2020). Motivasi Belajar Mahasiswa pada Pembelajaran Daring selama Pandemik COVID-19. Jurnal Kependidikan: Jurnal Hasil Penelitian dan Kajian Kepustakaan di Bidang Pendidikan, Pengajaran, dan Pembelajaran. Vol 6. (2) 165175.

Iskandar. (2016). Implementation of Model SAVI (Somatic, Audiotory, Visualization, Intellectual) to Increase Critical Thinking Ability in Class IV of Social Science 
Learning on Social Issues in The Local Environment. Journal of Education, Teaching and Learning. Vol. 1 (1) 45 - 50.

Noone \& Hogan. (2016). A protocol for a randomised activecontrolled trial to evaluate the effects of an online mindfulness intervention on executive control, critical thinking and key thinking dispositions in a university student sample. BMC Psychology. Vol. 4 (17) 1 - 12.

OECD. 2018. PISA Result in Focus. https://www.oecd.org/pisa/pisa-2015-results-infocus. pdf.

Rahayu, A., Nuryani, P., \& Riyadi, A.R. (2019). Penerapan Model Pembelajaran SAVI untuk Meningkatkan Aktivitas Belajar Siswa. Jurnal Pendidikan Guru Sekolah Dasar. Vol 4 (11) 102-111.

Susantini. (2016). Effectiveness Of Genetics Student Worksheet To Improve Creative Thinking Skills Of Teacher Candidate Students. Journal Of Science Education. Vol. 17 (2) $74-79$.

Thompson. (2011). Critical Thinking Across the Curriculum: Process Over Output. International Journal of Humanities and Social Science. Vol. 1 (9) 1-7.

Yildirim. (2011). The Effect Of The Worksheet On Students' Achievement In Chemical Equilibrium. Journal of The Turkish Science Education. Turki. Vol. 8 (3) 44-58. 